\title{
A role for cyclic nucleotide phosphodiesterase 4 in regulation of the growth of human malignant melanoma cells
}

\author{
MOTOSHI NARITA, TAKU MURATA, KASUMI SHIMIZU, TOSHIYUKI NAKAGAWA, \\ TAKEO SUGIYAMA, MADOKA INUI, KENICHI HIRAMOTO and TOSHIRO TAGAWA \\ Department of Oral and Maxillofacial Surgery, Faculty of Medicine, Mie University, Mie, Japan
}

Received November 14, 2006; Accepted December 23, 2006

\begin{abstract}
The activity, expression and function of phosphodiesterase 4 (PDE 4) were investigated in the HMG human gingiva-derived malignant melanoma cell line. A specific PDE4 inhibitor, rolipram, inhibited PDE activity in homogenates of HMG cells, and PDE4B and 4D mRNAs were detected by RT-PCR in RNA from HMG cells. Two specific PDE4 inhibitors, rolipram and Ro-20-1724, and an adenylate cyclase activator, forskolin, increased intracellular cAMP in HMG cells. Cell growth induced by rolipram, Ro-20-1724, and forskolin was inhibited by the $\mathrm{H}-89$ protein kinase $\mathrm{A}$ (PKA) inhibitor. However, in contrast to effects of H-89, two other PKA inhibitors, KT5720 and PKI, did not inhibit rolipram-induced cell growth. A cAMP analogue that selectively activates Epac, 8-pCPT-2'-O-Me-cAMP, also promoted the growth of HMG cells. These findings suggested that PDE4, PDE4B and/or 4D regulate cell growth through cAMP targets in the HMG malignant melanoma cell line. There have been no previous studies of positive regulation of cell growth by PDE4 inhibition, suggesting that it may be possible to target PDE4 in therapy for human malignant melanoma.
\end{abstract}

\section{Introduction}

cAMP acts as a second messenger in cells and modulates many physiological processes. Intracellular cAMP content is regulated through synthesis by adenylate cyclase and degradation by PDEs. cAMP binds to cAMP-dependent protein kinase (PKA) and regulates many functions primarily by activation of PKA (1). In mammals, type I and type II PKA exist, the localization of which varies in different tissues and cells, and the two types are considered to function individually (2). The discovery of a new cAMP target, Epac (cAMP-GEF), which is activated by direct binding of cAMP $(3,4)$, has

Correspondence to: Dr Motoshi Narita, Department of Oral and Maxillofacial Surgery, Faculty of Medicine, Mie University, 2-174 Edobashi, Tsu, Mie 514-8507, Japan

E-mail: nya@clin.medic.mie-u.ac.jp

Key words: human malignant melanoma, phosphodiesterase 4, phosphodiesterase 4 inhibitor modified somewhat the established theory that most physiological functions of cAMP are exerted through the activation of PKA.

Eisinger and Marko succeeded in culturing melanocytes from epidermal single-cell suspensions using a culture medium containing phorbol ester and cholera toxin (CT) (5), and Halaban et al reported a synergistic effect of isobutylmethyl xantine (IBMX), a non-specific PDE inhibitor, and/or CT on the growth stimulation of neonatal melanocytes in combination with 12-O-tetradecanoylphorbol-13-acetate (TPA) (6). IBMX and CT increase intracellular cAMP, suggesting that cAMP plays an important role in melanocyte growth. As IBMX inhibits several PDEs, it is not clear which PDE is involved in melanocyte growth.

The PDE enzyme family catalyzes the hydrolysis of intracellular cAMP and cGMP (1). PDEs are currently classified into 11 types on the basis of their affinity for these cyclic nucleotides, sensitivity to inhibitors, and primary structures. Most families are composed of more than one, but related, isogenes. Different mRNAs can be generated from the same gene by the use of multiple transcription initiation sites or by alternative mRNA splicing. PDE4 is a distinct multi-gene PDE family that is defined by sequence homology and is a low Km cAMP-specific enzyme that is inhibited by the antidepressant rolipram (7). There are four subfamilies of PDE4 (PDE4A, 4B, 4C, and 4D), and there are multiple splicing variants of each gene (8). PDE4s are expressed in various normal cells, including immuno/inflammatry cells, and regulate many physiological functions $(1,8,9)$. Furthermore, PDE4 is expressed in several types of tumor cells, and PDE4-specific inhibitors have been reported to inhibit cell growth (10). However, the role of PDE4 in human malignant melanoma cells is unknown. Herein, we provide the first evidence that PDE4 is expressed in these cells, and we show that specific inhibitors of PDE4 promote the growth of human malignant melanoma cells.

\section{Materials and methods}

Cell culture. Human gingiva-derived malignant melanoma HMG cells (11) were maintained in RPMI-1640 (Invitrogen Corp., Carlsbad, CA) containing 20\% fetal bovine serum (Invitrogen Corp.) with a condition of humidified atmosphere of $5 \% \mathrm{CO}_{2}$ in air at $37^{\circ} \mathrm{C}$. Cells were collected using $0.05 \%$ trypsin and $0.53 \mathrm{mM}$ EDTA solution (Invitrogen Corp.); a subculture was then performed every week. 
Table I. Primer sequence for PDE4.

\begin{tabular}{|c|c|c|}
\hline & Primer & $\begin{array}{l}\text { Product } \\
\text { size (bp) }\end{array}$ \\
\hline PDE4A & $\begin{array}{l}\text { 5'-AAC AGC CTG AAC AAC TCT AAC-3' } \\
\text { 5'-CAA TAA AAC CCA CCT GAG ACT-3' }\end{array}$ & 907 \\
\hline PDE4B & $\begin{array}{l}\text { 5'-AGC TCA TGA CCC AGA TAA GTG-3' } \\
\text { 5'-ATA ACC ATC TTC CTG AGT GTC-3' }\end{array}$ & 625 \\
\hline PDE4C & $\begin{array}{l}\text { 5'-TCG ACA ACC AGA GGA CTT AGG-3' } \\
\text { 5'-GGA TAG AAG CCC AG AGA AAG-3' }\end{array}$ & 289 \\
\hline PDE4D & $\begin{array}{l}\text { 5'-CGG AGA TGA CTT GAT TGT GAC-3' } \\
\text { 5'-CGT TCC TGA AAA ATG GTG TGC-3' }\end{array}$ & 641 \\
\hline
\end{tabular}

Preparation of cell extracts for cAMP PDE assay. The cells were seeded at $1 \times 10^{6}$ cells $/ 25 \mathrm{~cm}^{2}$ flask (Nunc, Roskilde, Denmark). After 3 days, cells were washed twice with phosphate-buffered saline (PBS), harvested with a rubber policeman, and homogenized in $2 \mathrm{ml}$ of ice-cold homogenization buffer (100 mM TES, pH 7.4, $10 \mu \mathrm{g} / \mathrm{ml}$ each of pepstain, leupeptin, and aprotinin, $1 \mathrm{mM}$ benzamidine, $0.5 \mathrm{mM}$ Pefabloc ${ }^{\circledR}$ SC(AEBSF), $1 \mathrm{mM}$ EDTA, $0.1 \mathrm{mM}$ EGTA, $5 \mathrm{mM}$ $\mathrm{MgSO}_{4}, 10 \%$ glycerol).

cAMP PDE assay. cAMP PDE activity was assayed by a modification of a previously described procedure (12). Samples were incubated at $30^{\circ} \mathrm{C}$ for $10 \mathrm{~min}$ in a total volume $(0.3 \mathrm{ml})$ containing $50 \mathrm{mM}$ Hepes, $\mathrm{pH} 7.4,0.1 \mathrm{mM}$ EGTA, $8.3 \mathrm{mM} \mathrm{MgCl}_{2}$, and $0.1 \mu \mathrm{M}(3 \mathrm{H}) \mathrm{cAMP}(18,000 \mathrm{cpm})$ with or without each PDE inhibitor. PDE inhibitors used are a specific inhibitor of PDE 1, 8-methoxymethyl-3-isobutyl-1methylxanthine (8-Me-IBMX); a specific inhibitor of PDE 2, erythro-9-(2-hydroxy-3-nonyl)adenine (EHMA); a specific inhibitor of PDE 3, cilostamide; and a specific inhibitor of PDE 4, rolipram.

RT-PCR for PDE4 isoforms. The cells were seeded at $1 \times 10^{6}$ cells $/ 25 \mathrm{~cm}^{2}$ flask (Nunc). After 3 days, cells were harvested with trypsin-EDTA solution and stored at $-80^{\circ} \mathrm{C}$. Total RNA was isolated with QuickPrep ${ }^{\circledR}$ Total RNA extraction kit (Amersham Biosciences, Corp., Piscataway, NJ). Firststrand cDNA was synthesized using $1 \mu \mathrm{g}$ total RNA with the SuperScript ${ }^{\mathrm{TM}}$ preamplification system (Invitrogen). PCR was performed with specific primer pairs for PDE4 isoforms (13) (Table I). These primers are able to detect all isoforms from a particular subfamily. RT product $(2 \mu \mathrm{l})$ was added to a PCR reaction, which included PCR buffer $(10 \mathrm{mM}$ Tris- $\mathrm{HCl}$, $\mathrm{pH} 8.3,50 \mathrm{mM} \mathrm{KCl}, 1.5 \mathrm{mM} \mathrm{MgCl}_{2}, 0.01 \%$ gelatin), $0.2 \mathrm{mM}$ dNTPs, $1 \mu \mathrm{M}$ primers, and 5 units of Taq DNA polymerase (Applied Biosystems, Foster City, CA). Thirty PCR cycles were followed by denaturation at $94^{\circ} \mathrm{C}$, annealing at $55^{\circ} \mathrm{C}$ and extension at $72^{\circ} \mathrm{C}$ with a GeneAmp 2400 thermal cycler (Applied Biosystems). Reaction products were analyzed by electrophoresis of $5 \mu 1$ samples in $2.5 \%$ agarose gels. The amplified DNA fragments were visualized by ethidium bromide staining.
Table II. Primer sequence for PDE4B.

\begin{tabular}{|c|c|c|}
\hline & Primer & $\begin{array}{l}\text { Product } \\
\text { size (bp) }\end{array}$ \\
\hline PDE4B1 & $\begin{array}{l}\text { 5'-GGA GAG GGA GAA GGT GC-3' } \\
\text { 5'-TGT GTC AGC TCC CGG TTC AGC-3' }\end{array}$ & 661 \\
\hline PDE4B2 & $\begin{array}{l}\text { 5'-AGC GGT GGT AGC GGT GAC TC-3' } \\
\text { 5'-GCA GCG TGC AGG CTG TTG TG-3' }\end{array}$ & 680 \\
\hline PDE4B3 & $\begin{array}{l}\text { 5'-CTC CAC GCA GTT CAC CAA GGA AC-3' } \\
\text { 5'-TGT GTC AGC TCC CGG TTC AGC-3' }\end{array}$ & 598 \\
\hline
\end{tabular}

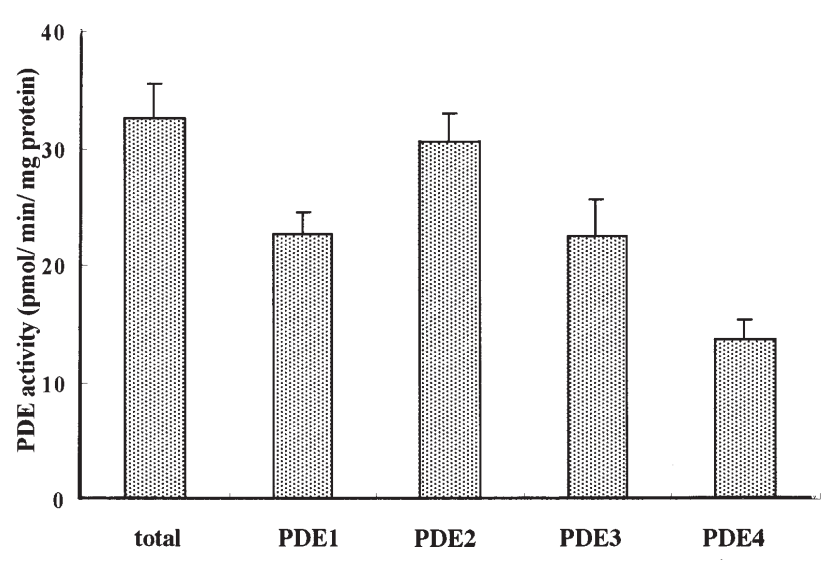

Figure 1. Effect of PDE inhibitors on PDE activity. Homogenates were prepared and assayed for PDE activity with or without each PDE-specific inhibitor as described in Materials and methods. Data are mean \pm SEM of three different experiments. Total (without PDE inhibitor), PDE1 (with 8-Me-IBMX), PDE2 (with EHNA), PDE3 (with cilostamide), PDE4 (with rolipram).

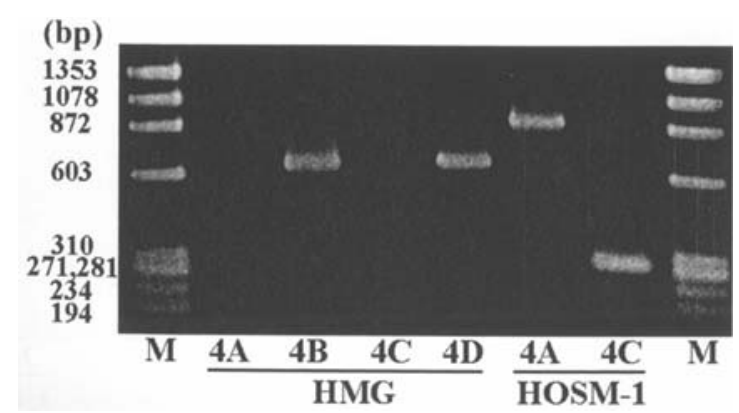

Figure 2. RT-PCR for PDE4 isoforms. Total RNA was extracted as described in Materials and methods. cDNA was generated from $1 \mu \mathrm{g}$ total RNA and amplified by PCR using oligonucleotide primer sets based on sequences from PDE4A, B, C and D. The products were separated on agarose gels and photographed after ethidium bromide staining. PDE4A (4A), PDE4B (4B), PDE4C (4C), PDE4D (4D), absence of RT (no RT), molecular markers (M). HOSM-1 cells were used as positive controls of PDE4A and PDE4C (9).

$R T-P C R$ for splicing variants of PDE4B and $4 D$. This was performed on HMG RNA using specific primers $(14,15)$ (Tables II and III) and the methodology described in RT-PCR for PDE4 isoforms. 
Table III. Primer sequence for PDE4D

\begin{tabular}{|c|c|c|}
\hline & Primer & $\begin{array}{l}\text { Product } \\
\text { size }(b p)\end{array}$ \\
\hline PDE4D1 & $\begin{array}{l}\text { 5'-CTT TCC CTG TCT CTT CGC-3' } \\
\text { 5'-TCA GAG AGA TGG GTG AGC-3' }\end{array}$ & 175 \\
\hline PDE4D2 & $\begin{array}{l}\text { 5'-AAG GAG CAG CCC TCA TGT-3' } \\
\text { 5'-TCA GAG AGA TGG GTG AGC-3' }\end{array}$ & 201 \\
\hline PDE4D3 & $\begin{array}{l}\text { 5'-GAC AGA AGA TCT GCG AAC-3' } \\
\text { 5'-TCA GAG AGA TGG GTG AGC-3' }\end{array}$ & 572 \\
\hline PDE4D4 & $\begin{array}{l}\text { 5'-ATC GCG GCT ACT CGG ACA-3' } \\
\text { 5'-TCA GAG AGA TGG GTG AGC-3' }\end{array}$ & 646 \\
\hline PDE4D5 & $\begin{array}{l}\text { 5'-ATG GCT CAG CAG ACA AGC-3' } \\
\text { 5'-TCA GAG AGA TGG GTG AGC-3' }\end{array}$ & 770 \\
\hline
\end{tabular}

The primer pair for PDE4D2 detect PDE4D1 (287 bp) and PDE4D2 (201 bp).

A

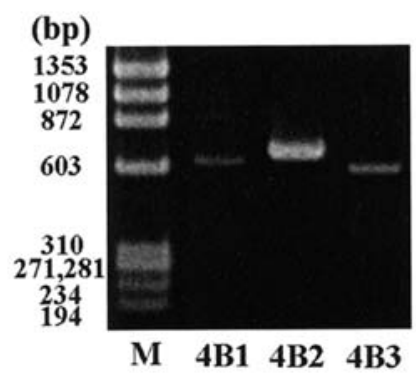

B

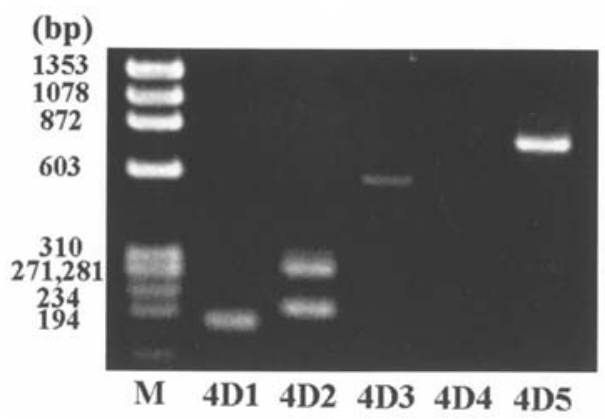

Figure 3. RT-PCR for splicing variants of PDE4B and PDE4D in HMG cells. (A) PDE4B, (B) PDE4D. Total RNA was extracted as described in Materials and methods. cDNA was generated from $1 \mu \mathrm{g}$ total RNA and amplified by PCR using oligonucleotide primer sets based on sequences from PDE4B and 4D splicing variants. The products were separated on agarose gels and photographed after ethidium bromide staining. PDE4B1 (B1), PDE4B2 (B2), PDE4B3 (B3), PDE4D1 (D1), PDE4D2 (D2), PDE4D3 (D3), PDE4D4 (D4), molecular markers (M).

Growth experiments. The cells were plated at $0.5 \times 10^{4}$ cells/ well in 24-well plate and allowed to adhere for $24 \mathrm{~h}$. The cells were cultured in the absence or presence of different concentrations of reagents for 7 days. 3-(4,5-dimethylthiazol2-yl)-2,5-dipfenyl tetrazolium bromide (MTT) assays were performed and cell numbers were calculated. Each reagent was resolved in DMSO as vehicle. The growth and morphology
Table IV. Effect of rolipram, Ro-20-1724 and forskolin on the cAMP content of HMG cells.

\begin{tabular}{lcc}
\hline & \multicolumn{2}{c}{ cAMP concentration (fmol/well) } \\
\hline Control & 229.8 & \pm 41.4 \\
Rolipram & 421.6 & \pm 60.8 \\
Ro-20-1724 & 304.4 & \pm 33.8 \\
Forskolin & 1524.4 & \pm 275.0 \\
\hline
\end{tabular}

The cells were plated at $5 \times 10^{4}$ cells/60-mm dish and cultured with vehicle (control), rolipram $(20 \mu \mathrm{M})$, Ro-20-1724 $(0.5 \mu \mathrm{M})$ or forskolin $(0.5 \mu \mathrm{M})$ reagents for $30 \mathrm{~min}$. The intracellular cAMP concentration was determined as described in Materials and methods. Data are mean \pm SEM of three different experiments.

of the cells were not affected by the $0.05 \%$ concentration of DMSO used in these experiment.

cAMP concentration in HMG cells. HMG cells were plated at $5 \times 10^{4}$ cells/60-mm dish and allowed to adhere for $24 \mathrm{~h}$. Then, the cells were incubated with medium containing indicated concentrations of reagents for $30 \mathrm{~min}$. Intracellular cAMP content was determined using the cAMP Biotrak enzyme immunoassay (EIA) system (Amersham Biosciences).

\section{Results}

cAMP PDE activity. In homogenates of HMG cells, PDE activities were inhibited by the PDE1-specific inhibitor, 8-MeIBMX, the PDE3-specific, cilostamide, and the PDE4-specific inhibitor, rolipram, suggesting the presence of PDE1, 3 and 4 enzymes. However, PDE activities were not inhibited by the PDE2-specific inhibitor, EHNA (Fig. 1). Furthermore, we found that PDE activity in HMG cells was not stimulated by cGMP, and PDE2 mRNAs were not detected in RNA extracted from HMG cells using RT-PCR (data not shown).

Expression of PDE4 isoforms and splicing variants of PDE4B and $4 D$. RT-PCR was performed using human PDE4A-, 4B-, 4C- and 4D-specific primers. PDE4B and 4D mRNAs, but not PDE4A or PDE4C, were detected in RNA extracted from HMG cells (Fig. 2), and their sequences were identical to those reported for human PDE4B (16) and 4D (17). Previous studies have confirmed the presence of 3 and 8 splicing variants of PDE4B and 4D, respectively, in humans $(14,15,18,19)$. In HMG cells, 3 splicing variants of PDE4B (PDE4B1, 4B2, and 4B3) and 4 of PDE4D (PDE4D1, 4D2, 4D3, and 4D5) were detected (Fig. 3A and B). PDE4D6, 4D7 and 4D8 were not investigated in this study.

Effect of reagents on HMG cell growth. The PDE4-specific inhibitor, rolipram, promoted the growth of HMG cells in a concentration-dependent manner (Fig. 4A). Another specific PDE4 inhibitor, Ro-20-1724, exhibited a similar effect (Fig. 4B). In addition, an adenylate cyclase activator, forskolin, promoted cell growth at concentrations of $\geq 1 \mu \mathrm{M}$ 
A

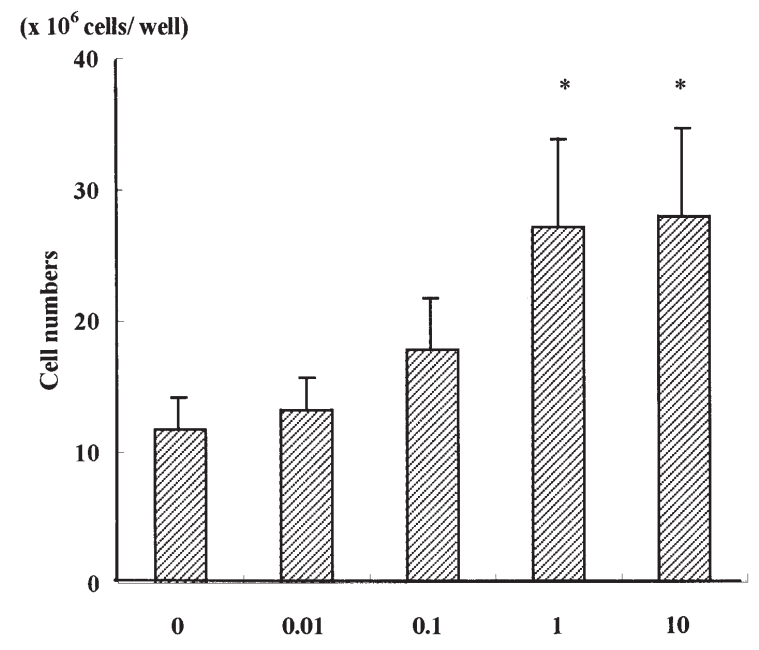

( $\mu$ M rolipram)

B

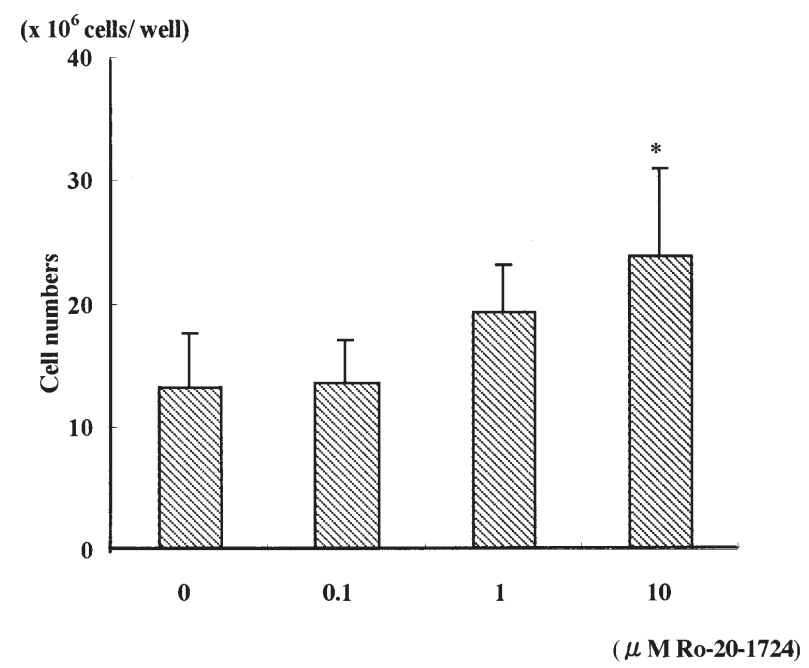

C

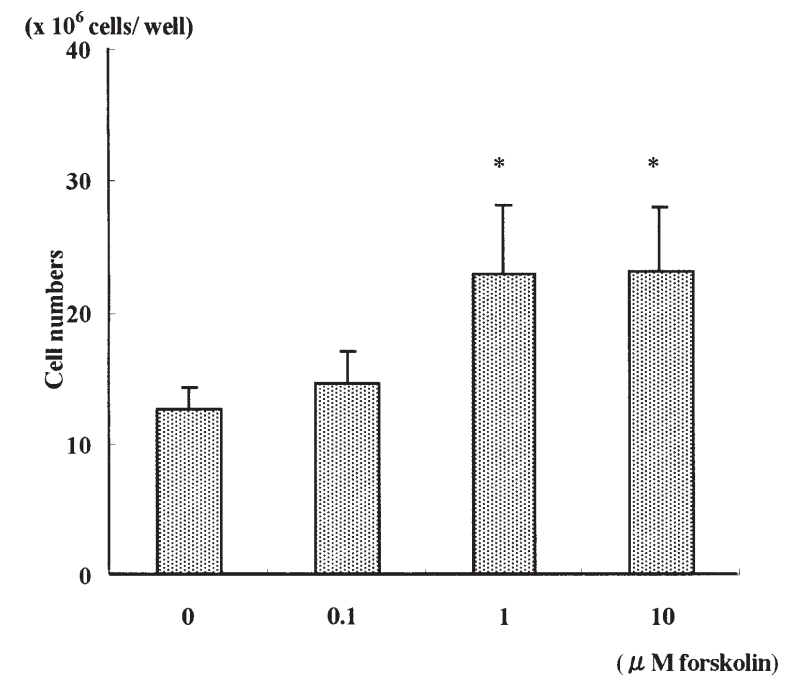

Figure 4. Effect of reagents on HMG cell growth. Cells were plated at $0.5 \times 10^{4}$ cells/well in 24 -well plates and cultured with different concentrations of reagent. After 7 days, MTT assays were performed and cell numbers were calculated. Each reagent stimulated the growth of HMG cells dose-dependently. Data are mean \pm SEM of three different experiments. Significantly different from the control $\left({ }^{*} \mathrm{p}<0.05\right)$. (A) rolipram, (B) Ro-20$1724,(\mathrm{C})$ forskolin.

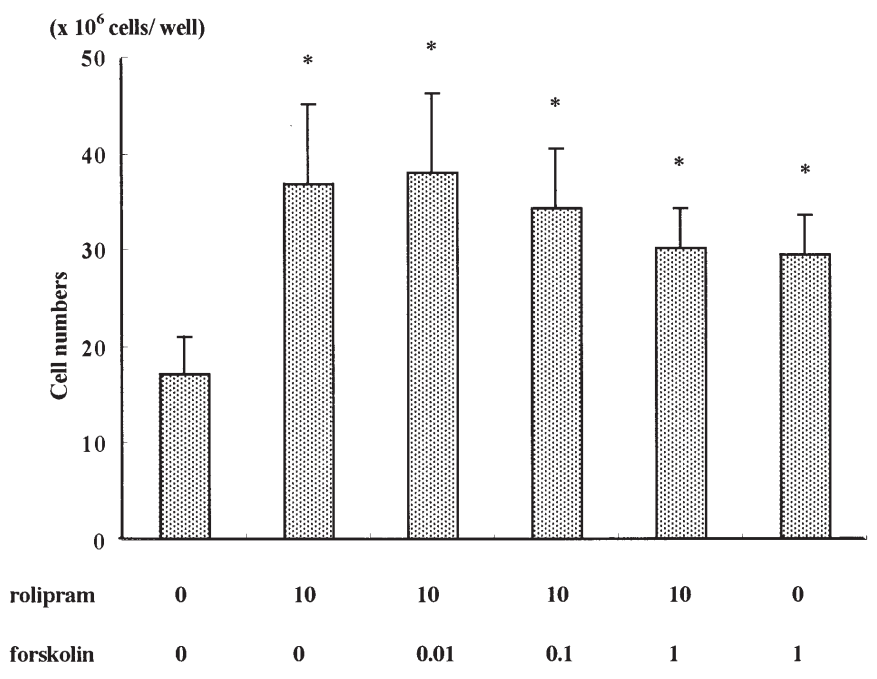

$(\mu \mathbf{M})$

Figure 5. Effect of combination of rolipram and forskolin on HMG cell growth. Cells were plated at $0.5 \times 10^{4}$ cells/well in 24-well plates and cultured with different concentrations of reagents. After 7 days, MTT assays were performed and cell numbers were calculated. Data are mean \pm SEM of three different experiments. Significantly different from the control $\left({ }^{*} \mathrm{p}<0.05\right)$

(Fig. 4C). However, the PDE1-specific inhibitor, 8-Me-IBMX, the PDE2-specific inhibitor, EHMA, and the PDE3-specific, cilostamide, did not promote the growth of HMG cells (data not shown). No effect was observed of combination of rolipram and forskolin on the growth of HMG cells (Fig. 5).

Effect of PKA inhibitors on HMG cell growth. The promotion of HMG cell growth by rolipram, Ro-20-1724, and forskolin was significantly inhibited by the PKA inhibitor H-89, at a concentration of $20 \mu \mathrm{M}$ (Fig. 6A), but not $0.5 \mu \mathrm{M}$ KT5270 (Fig. 6B) and 0.5 $\mu \mathrm{M}$ PKI14-22 (Fig. 6C). Treatment with $20 \mu \mathrm{M} \mathrm{H}-89,0.5 \mu \mathrm{M}$ KT5270 or $0.5 \mu \mathrm{M}$ PKI14-22 alone did not affect HMG cell growth (data not shown).

cAMP concentration in HMG cells. To determine whether rolipram, Ro-20-1724 and forskolin would affect cAMP concentration in HMG cells, we assessed intracellular cAMP concentration after $30 \mathrm{~min}$ of incubation with each reagent. These reagents increased cAMP content of HMG cells (Table IV).

Effect of an Epac-selective cAMP analog on HMG cell growth. In order to clarify the mechanism of the specific growth promotion in HMG cells, we studied the effect of an Epacspecific cAMP analog, 8-pCPT-2'-O-Me-cAMP, on growth of HMG cells. 8-pCPT-2'-O-Me-cAMP promoted HMG cell growth at concentrations of $\geq 10 \mu \mathrm{M}$ (Fig. 7).

\section{Discussion}

Normal melanocytes were previously difficult to culture; however, the use of CT and/or IBMX, which lead to an increase in cAMP, has allowed culturing of such cells $(5,6)$. $\mathrm{CT}$ is considered to activate adenylate cyclase and increase the intracellular cAMP concentration, while IBMX is a 
A

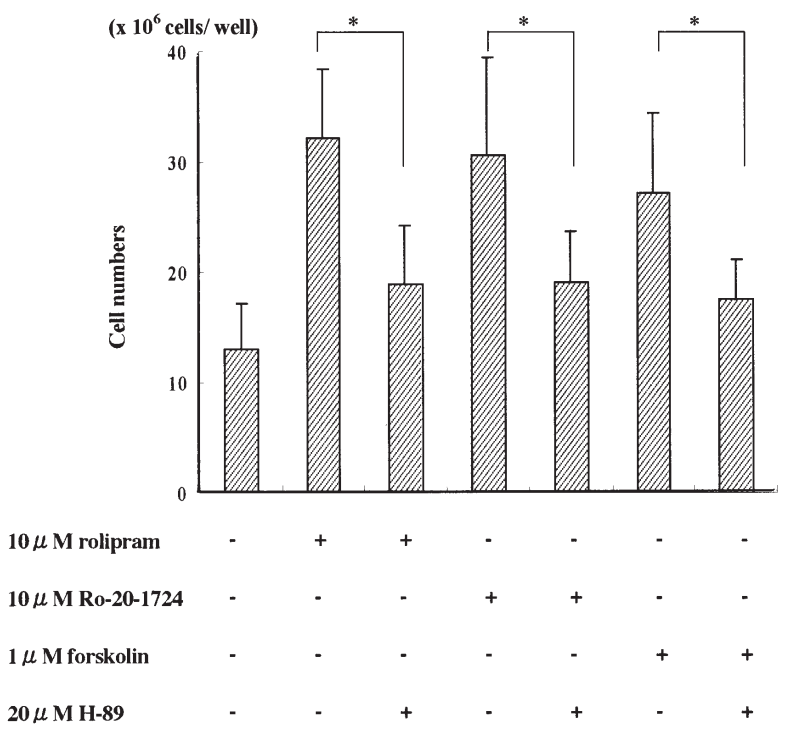

B

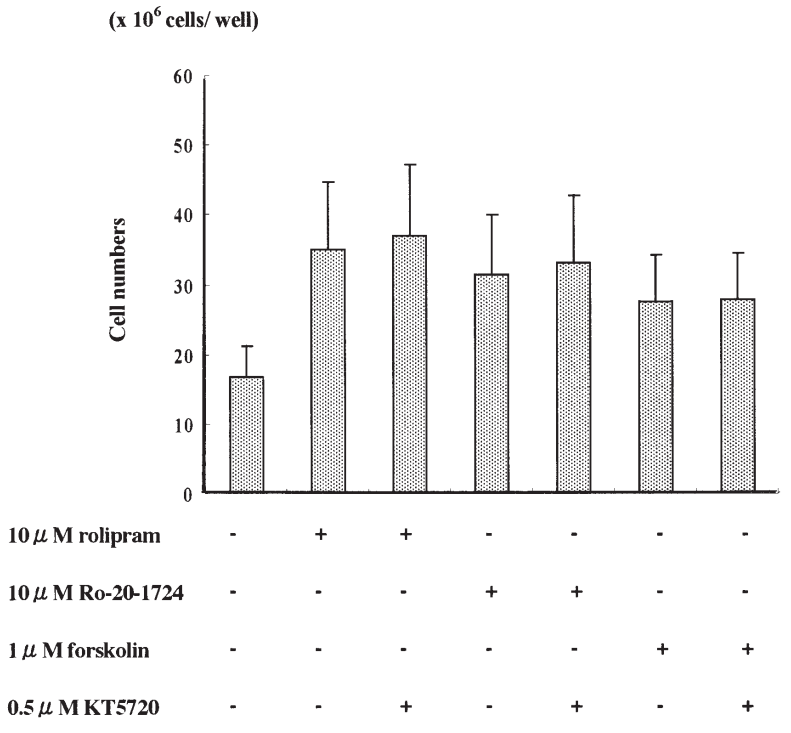

C

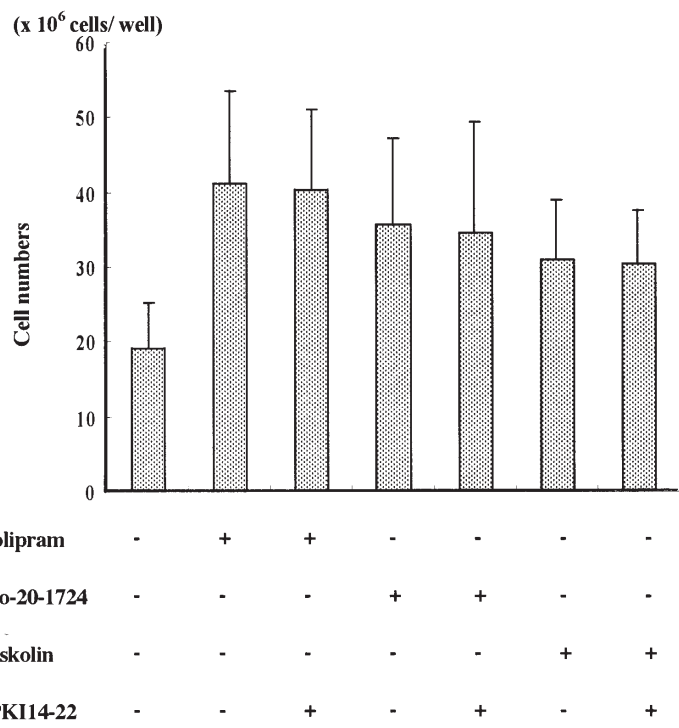

Figure 6. Effect of PKA inhibitors on rolipram, Ro-20-1724 and forskolin induced cell growth. Cells were plated at $0.5 \times 10^{4}$ cells/well in 24 -well plates and cultured with different concentrations of reagent. After 7 days, MTT assays were performed and cell numbers were calculated. Data are mean \pm SEM of three different experiments. Significantly different between reagent and reagent plus H-89 ('p<0.05). (A) H-89, (B) KT5720, (C) PKI14-22.

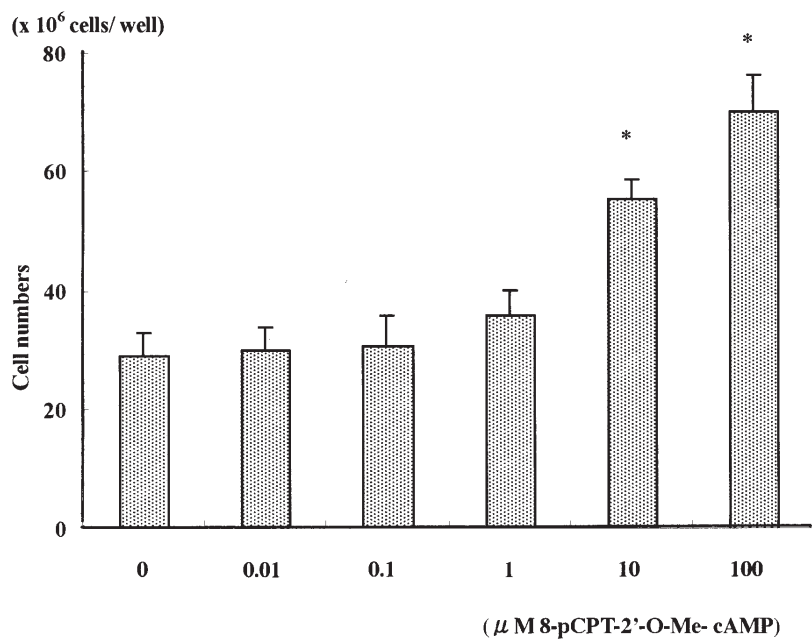

Figure 7. Effect of Epac-selective cAMP analog on HMG cell growth. Cells were plated at $0.5 \times 10^{4}$ cells/well in 24 -well plates and cultured with different concentrations of 8-pCPT-2'-O-Me-cAMP. After 7 days, MTT assays were performed and cell numbers were calculated. Data are mean \pm SEM of three different experiments. Significantly different from the control $\left({ }^{*} \mathrm{p}<0.05\right)$

non-specific inhibitor of PDEs and is considered to increase the intracellular cAMP concentration by inhibiting cAMP hydrolysis. As IBMX is a non-specific inhibitor of PDEs, it is necessary to determine which PDE isoform regulates melanocyte growth.

Since malignant melanoma is considered to originate from activated or genetically altered melanocytes (20), signal transduction pathways related to melanocyte growth may be preserved in at least some types of malignant melanoma. Hence, the analysis of signals common to melanocytes and malignant melanoma is very useful for understanding the properties of these cells. Forskolin, which increases the cAMP concentration in HMG cells, was shown to stimulate HMG cell growth, suggesting that cAMP-mediated signaling pathway for cell growth are present in HMG cells, as in normal melanocytes.

PDE4 is formed by four gene groups and has been detected in various tissues and cells (1). Expression of PDE4 has been demonstrated in several types of malignant tumor cells, and growth inhibition of normal and tumor cells by PDE4 inhibitors has been reported $(9,13)$. Although PDE4 activity has been detected in B16 murine melanoma cells by Mono-Q exchange chromatography and a specific PDE4 inhibitor, DC-TA-46, was shown to inhibit cell growth (10), it is not known which PDE4 isoforms are expressed in these cells. Futhermore, there have been no studies of involvement of PDE4 in the growth of human malignant melanoma cells. When the HMG cell lysate was treated with rolipram, $50 \%$ of total PDE activity was inhibited, confirming the presence of PDE4. Using specific oligonucleotide primers, PDE4B and PDE4D mRNAs were detected by RT-PCR in RNA from HMG cells. These results were consistent with the inhibition of HMG PDE activity by polipram and Ro-20-1724.

There are multiple splicing variants of each of the PDE4A, 4B, 4C, and 4D genes. Currently, at least three PDE4B splice variants (4B1, 4B2, and 4B3) and eight PDE4D splice variants (4D1, 4D2, 4D3, 4D4, 4D5, 4D6, 4D7, and 4D8) have been 
identified $(14,15,18,19)$. Since mRNAs for PDE4B and PDE4D were detected in HMG cells, the presence of each splice variant was examined. RT-PCR analysis was performed using primers specific for each splice variant, and PDE4B1, 4B2, and 4B3 and PDE4D1, 4D2, 4D3, and 4D5 mRNAs were detected. PDE4D6, 4D7, and 4D8 mRNAs were not investigated in the present study. The roles of the PDE4B and PDE4D isoforms in cells are not yet fully understood. Huston et al found that alternatively spliced PDE4B regions determine changes in the maximal catalytic activity of the isoforms, their susceptibility to inhibition by rolipram, and their mode of interaction with particulate fractions (14). Differences in PDE4D isoform activation by PKA-dependent mechanisms and expression in tissues have also been reported (19).

cAMP acts as a second messenger in cells and is involved in various physiological processes. The cAMP concentration is regulated through synthesis by adenylate cyclase and degradation by PDEs (1). In HMG cells, forskolin, rolipram and Ro-20-1724 elevated the intracellular cAMP concentration, and both PDE4 inhibitors, rolipram and Ro-20-1724, promoted HMG growth. Since promotion of cell growth by PDE4 inhibitors has not previously been reported, this finding suggests a function of PDE4 in these cells; the negative regulation of cell growth.

cAMP mainly binds to cAMP-dependent protein kinase (PKA) and regulates many processes by the activation of PKA. The PKA inhibitor H-89, partially inhibited rolipram-induced promotion of HMG cell growth; however, other PKA inhibitors, KT5720 and PKI14-22, exhibited almost no inhibitory effect on rolipram-induced promotion of HMG cell growth. In addition to inhibition of PKA, H-89 has been reported to inhibit several protein kinases, such as S6K1, MSK1, and ROCK-II, at a concentration similar to or lower than that required for the inhibition of PKA (21). It is not clear whether roliplam-induced promotion of HMG cell growth is regulated by PKA. Epac (cAMP-GEF) was identified in 1998 as a protein that directly binds to cAMP and exhibits GEF activity on $\operatorname{Rap} 1(3,4)$. A cAMP analog that has a higher affinity for Epac than for PKA, 8-pCPT-2'-O-Me-cAMP, has been developed (22), and, we found that 8-pCPT-2'-O-MecAMP promotes the growth of HMG cells, suggesting that Epac activation is also involved in HMG cell growth.

It has been reported that B-raf, which activates the MEKERK cascade involved in cell growth, is mutated in malignant melanoma at a high frequency and may be one of the causative genes for malignant melanoma (23). B-raf is activated by cAMP in melanocytes (24), while, in rat phaeochromocytoma PC12 cells, Rap1 activates B-raf (25). Both cell types are derived from the neural crest (26). Based on these findings, cAMP-bound Epac might activate B-raf after it activates Rap1 in these cells, resulting in the activation of the MAP kinase cascade. It is of interest to confirm the mutation of B-raf in HMG and investigate the activation of B-raf by PDE4 inhibitors.

We have previously confirmed the expression and activity of PDE3 in HMG cells, but a specific PDE3 inhibitor, cilostamide, did not alter cell growth, indicating that PDE3 is not involved in HMG cell growth (27). In HMG cells PDE4, but apparently not PDE1 and PDE3, regulates cell growth. This finding is consistent with the concept of compartmentalization, through which PDE3 and PDE4 regulate different cAMP signaling pathways (28).

Based on the above, cAMP may play an important role in the growth of HMG cells, as well as in melanocytes, and PDE4B and/or 4D may be involved in cAMP regulation in HMG cells. If PDE4B and/or 4D negatively regulate cell growth, either enzyme may be a new target for melanoma therapy through the introduction of genes for growth inhibition. For the development of such an approach, it will first be necessary to determine whether PDE4B or 4D is involved in the signaling associated with negative growth regulation.

\section{Acknowledgements}

We are grateful to Professor Vincent C. Manganiello of Pulmonary/Critical Care Medicine Branch, National Institutes of Health for discussions and for reading the manuscript.

\section{References}

1. Manganiello VC and Degerman E: Cyclic nucleotide phosphodiesterases (PDEs): Diverse regulators of cyclic nucleotide signals and inviting molecular targets for novel therapeutic agents. Tromb Haemost 82: 407-411, 1999.

2. Cho-Chung YS: Role of cyclic AMP receptor proteins in growth, differentiation, and suppression of malignancy: new approaches to therapy. Cancer Res 50: 7093-7100, 1990.

3. de Rooji J, Zwartkruis FJT, Verheijen MHG, Cool RH, Nijman SMB, Wittinghofer A, et al: Epac is a Rap1 guaninenucleotide-exchange factor directly activated by cyclic AMP. Nature 396: 474-477, 1998.

4. Kawasaki H, Springett GM, Mochizuki N, Toki S, Nakaya M, Matsuda M, et al: A family of cAMP-binding proteins that directly activate Rap1. Science 282: 2275-2279, 1998.

5. Eisinger M and Marko O: Selective proliferation of normal human melanocytes in vitro in the presence of phorbol ester and cholera toxin. Proc Natl Acad Sci USA 79: 2018-2022, 1982.

6. Halaban R, Ghosh S, Duray P, Kirkwood JM and Lerner AB: Human melanocytes cultured from nevi and melanomas. J Invest Dermatol 87: 95-101, 1986.

7. Livi GP, Kmetz P, McHale MM, Cieslinski LB, Sathe GM, Taylor DP, et al: Cloning and expression of cDNA for a human low-Km, rolipram-sensitive cyclic AMP phosphodiesterase. Mol Cell Biol 10: 2678-2686, 1990.

8. Houslay MD: PDE4 cAMP-specific phosphodiesterases. Prog Nucleic Acid Res Mol Biol 69: 249-315, 2001.

9. Narita M, Murata T, Shimizu K, Sugiyama T, Nakagawa T, Manganiello VC, et al: Phosphodiesterase 4 in osteoblastic osteosarcoma cells as a potential target for growth inhibition. Anticancer Drugs 14: 377-381, 2003.

10. Drees M, Zimmermann R and Eisenbrand G: 3', 5'-cyclic nucleotide phosphodiesterase in tumor cells as potential target for tumor growth inhibition. Cancer Res 53: 3058-3061, 1993.

11. Tagawa T, Yatani R, Nishioka H and Murata M: Primary malignant melanoma of the oral cavity. Case report and establishment of melanoma cell line. Int J Oral Surg 10: 16-20, 1981

12. Degerman E, Moos M Jr, Rascón A, Vasta V, Meacci E, Smith CJ, et al: Single-step affinity purification, partial structure and properties of human platelet cGMP inhibited cAMP phosphodiesterase. Biochim Biophys Acta 1205: 189-198, 1994.

13. Ekholm D, Mulloy JC, Gao G, Degerman E, Franchini G and Manganiello VC: Cyclic nucleotide phosphodiesterases (PDE) 3 and 4 in normal, malignant, and HTLV-I transformed human lymphocytes. Biochem Pharmacol 58: 935-950, 1999.

14. Huston E, Lumb S, Russell A, Catterall C, Ross AH, Steele MR, et al: Molecular cloning and transient expression in COS7 cells of a novel human PDE4B cAMP-specific phosphodiesterase, HSPDE4B3. Biochem J 328: 549-558, 1997.

15. Miro X, Casacuberta JM, Gutiérrez-López MD, de Landázuri MO and Puigdomenech P: Phosphodiesterases 4D and 7A splicing variants in the response of HUVEC cells to TNF- $\alpha$. Biochem Biophys Res Commun 274: 415-421, 2000. 
16. McLaughlin MM, Cieslinski LB, Burman M, Torphy TJ and Livi GP: A low-Km, rolipram-sensitive, cAMP-specific phosphodiesterase from human brain. J Biol Chem 268: 6470-6476, 1993.

17. Némos G, Zhang R, Sette C and Conti M: Identification of cyclic AMP-phosphodiesterase variants from the PDE4D gene expressed in human peripheral mononuclear cells. FEBS Lett 384: 97-102, 1996

18. Houslay MD, Scotland G, Erdogan S, Huston E, Mackenzie S, McCallum JF, et al: Intercellular targeting, interaction with Src homology 3 (SH3) domains and rolipram-detected conformational switches in cAMP-specific PDE4A phosphodiesterase. Biochem Soc Trans 25: 374-381.

19. Wang D, Deng C, Bugaj-Gaweda B, Kwan M, Gunwaldsen C, Leonard C, et al: Cloning and characterization of novel PDE4D isoforms PDE4D6 and PDE4D7. Cell Signal 15: 883-891, 2003.

20. Slominski A, Wortsman J, Carlson AJ, Matsuoka LY, Balch CM and Mihm MC: Malignant melanoma. Arch Pathol Lab Med 125: 1295-1306, 2001

21. Davies SP, Reddy H, Caivano M and Cohen P: Specificity and mechanism of action of some commonly used protein kinase inhibitors. Biochem J 351: 95-105, 2000.
22. Enserink JM, Christensen AE, de Rooij J, vas Triest M, Schwede F, Genieser HG, et al: A novel Epac-specific cAMP analogue demonstrates independent regulation of Rap1 and ERK. Nat Cell Biol 4: 1-6, 2002.

23. Davies H, Bignell GR, Cox C, Stephens P, Edkins S, Clegg S, et al: Mutation of the BRAF gene in human cancer. Nature 417: 949-954, 2002.

24. Busca R, Abbe P, Mantoux F, Aberdam E, Peyssonnaux C, Eychene A, et al: Ras mediates the cAMP-dependent activation of extracelluler signal-regulated kinases (ERKs) in melanocytes. EMBO J 19: 2900-2910, 2000

25. York RD, Yao H, Dillon T, Ellig CL, Eckert SP, McCleskey EW, et al: Rap1 mediates sustained MAP kinase activation induced by nerve growth factor. Nature 392: 622-626, 1998.

26. Busca R and Ballotti R: Cyclic AMP a key messenger in the regulation of skin pigmentation. Pigm Cell Res 13: 60-69, 2000.

27. Murata T, Shimizu K, Narita M, Manganiello VC and Tagawa T: Characterization of phosphodiesterase 3 in human malignant melanoma cell line. Anticancer Res 22: 3171-3174, 2002.

28. Chini CC, Grande JP, Chini EN and Dousa TP: Compartmentalization of cAMP signaling in mesangial cells by phosphodiesterase isozymes PDE3 and PDE4. Regulation of superoxidation and mitogenesis. J Biol Chem 272: 9854-9859, 1997. 